US Army Corps of Engineers $s_{\circledast}$

Engineer Research and

Development Center

\title{
Metal Accumulation Capacity in Indigenous Alaska Vegetation Growing on Military Training Lands
}

Ryan R. Busby, Thomas A. Douglas, Joshua J. LeMonte,

August 2021

David B. Ringelberg, and Karl J. Indest 
The U.S. Army Engineer Research and Development Center (ERDC) solves the nation's toughest engineering and environmental challenges. ERDC develops innovative solutions in civil and military engineering, geospatial sciences, water resources, and environmental sciences for the Army, the Department of Defense, civilian agencies, and our nation's public good. Find out more at www.erdc.usace.army.mil.

To search for other technical reports published by ERDC, visit the ERDC online library at https://erdclibrary.on.worldcat.org/discovery. 


\section{Metal Accumulation Capacity in Indigenous Alaska Vegetation Growing on Military Training Lands}

Ryan R. Busby

Construction Engineering Research Laboratory

U.S. Army Engineer Research and Development Center

2902 Newmark Drive

Champaign, IL 61822

Thomas A. Douglas, Joshua J. LeMonte, and Karl J. Indest

Cold Regions Research and Engineering Laboratory

U.S. Army Engineer Research and Development Center

Fort Wainwright, AK and 72 Lyme Road, Hanover, NH 03755

David B. Ringelberg

Environmental Laboratory

U.S. Army Engineer Research and Development Center

3909 Halls Ferry Road

Vicksburg, MS 39180

Final report

Approved for public release; distribution is unlimited.

Prepared for U.S. Army Corps of Engineers

Washington, DC 20314

Under Environmental Quality 6.2 Applied Research Program 


\section{Preface}

This study was conducted for the U.S. Army Corps of Engineers (USACE) under the U.S. Army Environmental Quality 6.2 Applied Research Program.

The work was performed by the Engineer Research and Development Center, Construction Engineering Research Laboratory (ERDC-CERL), ERDC Cold Regions Research and Engineering Laboratory (ERDC-CRREL), and the ERDC Environmental Laboratory (ERDC-EL). At the time of publication of this paper, the Acting Deputy Director of ERDC-CERL was Ms. Michelle Hanson and the Director was Dr. Andrew Nelson, the Deputy Director for ERDC-CRREL was Mr. David Ringelberg and the Director was Dr. Joseph Corriveau, and the Deputy Director of ERDC-EL was Dr. Brandon Lafferty and the Director was Dr. Edmund J. Russo Jr.

This article was originally published online in the International Journal of Phytoremediation on 23 February 2020.

The authors would like to thank Mr. Anthony Bednar, Mr. Andrew Bray, Ms. Jenifer Milam, and Mr. Jared Smith of the Environmental Laboratory's Analytical Chemistry Laboratory for analyzing metal samples, and Ms. Sarah Kania at the University of Illinois for sample preparation.

The Commander of ERDC was COL Teresa A. Schlosser and the Director was Dr. David W. Pittman.

DISCLAIMER: The contents of this report are not to be used for advertising, publication, or promotional purposes. Citation of trade names does not constitute an official endorsement or approval of the use of such commercial products. All product names and trademarks cited are the property of their respective owners. The findings of this report are not to be construed as an official Department of the Army position unless so designated by other authorized documents. 


\title{
Metal accumulation capacity in indigenous Alaska vegetation growing on military training lands
}

\begin{abstract}
Permafrost thawing could increase soil contaminant mobilization in the environment. Our objective was to quantify metal accumulation capacities for plant species and functional groups common to Alaskan military training ranges where elevated soil metal concentrations were likely to occur. Plant species across multiple military training range sites were collected. Metal content in shoots and roots was compared to soil metal concentrations to calculate bioconcentration and translocation factors. On average, grasses accumulated greater concentrations of $\mathrm{Cr}, \mathrm{Cu}, \mathrm{Ni}, \mathrm{Pb}, \mathrm{Sb}$, and $\mathrm{Zn}$ relative to forbs or shrubs, and bioconcentrated greater concentrations of $\mathrm{Ni}$ and $\mathrm{Pb}$. Shrubs bioconcentrated greater concentrations of Sb. Translocation to shoots was greatest among the forbs. Three native plants were identified as candidate species for use in metal phytostabilization applications. Elymus macrourus, a grass, bioconcentrated substantial concentrations of $\mathrm{Cu}, \mathrm{Pb}$, and $\mathrm{Zn}$ in roots with low translocation to shoots. Elaeagnus commutata, a shrub, bioconcentrated the greatest amounts of $\mathrm{Sb}, \mathrm{Ni}$, and $\mathrm{Cr}$, with a low translocation factor. Solidago decumbens bioconcentrated the greatest amount of $\mathrm{Sb}$ among the forbs and translocated the least amount of metals. A combination of forb, shrub, and grass will likely enhance phytostabilization of heavy metals in interior Alaska soils through increased functional group diversity.
\end{abstract}

\section{Introduction}

Permafrost thawing in northern latitudes has accelerated in recent years (O'Donnell et al. 2012) and has led to changes in soil hydrology and biogeochemistry (Frey and McClelland 2009; Douglas et al. 2014; Brown et al. 2015). These alterations increase the likelihood that soil constituents will become more mobile in the environment, including heavy metals. While it is widely known that heavy metals can accumulate in shooting range soils (Sanderson et al. 2012; Bandara and Vithanage 2016; Rodríguez-Seijo et al. 2016a), metal concentrations occurring in impact areas and at detonation sites due to live fire training have not been fully characterized.

Metals observed to occur in blast residues from ordnance commonly detonated in impact areas include $\mathrm{Cu}, \mathrm{Ni}, \mathrm{Pb}$, and $\mathrm{Zn}$ (Walsh 2004). Copper, $\mathrm{Ni}$, and $\mathrm{Zn}$ have also been detected in soils surrounding open burning/open detonation sites (Martin et al. 2012). Bullets are primarily comprised of $\mathrm{Pb}$ and $\mathrm{Sb}$, but also contain $\mathrm{Ag}$, $\mathrm{As}, \mathrm{Bi}$, and $\mathrm{Ni}$, while bullet jackets are comprised predominantly of $\mathrm{Cu}$ and $\mathrm{Zn}$ (see Ahmad et al. 2012). Small arms ranges can receive Ag, As, $\mathrm{Cr}, \mathrm{Cu}, \mathrm{Ni}, \mathrm{Pb}, \mathrm{Sb}$, and $\mathrm{Zn}$, due to live fire exercises, although $\mathrm{Ag}$ and As are usually only present at lower concentrations (Sanderson et al. 2012; Bandara and Vithanage 2016; Rodríguez-Seijo et al. 2016a).

Because metals are not biodegradable but can bioaccumulate, limiting their movement within and through the environment is often a key objective for managing adverse effects (Ali et al. 2013). Plant stabilization of metals is important in preventing surface and groundwater contamination (Conesa et al. 2012; Evangelou et al. 2012). Phytostabilization is one such technique, whereby plants are used to uptake and immobilize metals. Uptake and sequestration with root tissues minimize the likelihood of bioaccumulation in other organisms and both vertical and horizontal transport through and over the soil profile (Ali et al. 2013). With respect to phytostabilization, the most effective plant species will possess a high bioconcentration factor (BCF), the ratio of plant root concentration to soil concentration (Zhuang et al. 2007), while possessing a low translocation factor (TF), the ratio of shoot concentration to root concentration (Padmavathiamma and Li 2007). Thus, ideal plants for phytostabilization accumulate high concentrations of metals from the soil, keep the metals concentrated in root tissues, and prevent metal translocation to shoots.

Most research involving metal phytoremediation has focused on phytoextraction, or the accumulation of metals 
in shoots for eventual harvest and removal (Pinto et al. 2015). A number of hyperaccumulators have been identified (Reeves et al. 2018). Unfortunately, few plant species have been investigated for their ability to stabilize metals from soils, and almost no species adapted to high latitude environments have been investigated. Vegetation occurring in soils where heavy metal deposition has occurred are ideal candidates for phytostabilization applications, largely due to the documented toxicity of heavy metals in soils (Pinto et al. 2015). Promising phytostabilization species have been identified in soils containing heavy metal contamination (Robinson et al. 2008; Álvarez-Ayuso et al. 2012; Selonen et al. 2012). However, many environmental variables influence metal phytostabilization, to include metal speciation and concentration, soil physical and biogeochemical characteristics, and climatic conditions (Pinto et al. 2015). How an individual plant species and/or a plant functional group may uptake a metal across an environmental gradient is not fully understood, and how Arctic and subarctic vegetation behaves relative to temperate and tropical vegetation is largely unknown. The objective of this study was to test the hypothesis that different functional groups of Arctic/subarctic vegetation differ in their abilities to accumulate metals from soils. To test this hypothesis, we quantified metal accumulation capacities for plant species and plant functional groups commonly occurring on Alaskan military training ranges where elevated soil metal concentrations were likely to occur. The research goal is to identify Arctic and subarctic region plant functional groups and species with potential for use in the phytostabilization of metals-affected soils.

\section{Materials and methods}

\section{Study sites}

Study sites were located at Fort Greely, AK (Figure S1, Supporting Material). The study area is a continental subarctic climate, with a mean annual temperature of $-2.6{ }^{\circ} \mathrm{C}$, and receives $309 \mathrm{~mm}$ of precipitation annually, with approximately $1 / 3$ occurring as snow. A number of sites were identified representing a variety of military training activities where metal deposition and accumulation were likely to occur. These sites included small arms firing ranges, munition target sites (impact areas), and explosive detonation sites where artillery propellant packets were ignited for disposal (Table 1).

\section{Vegetation and soil sampling}

Sample collection occurred the first week of August 2017. Dominant plant species with a minimum of three replicate individuals present at each site location were collected and identified to species (Hultén 1968; Welsh 1974) (Table 1). Three replicates of each plant species were then excavated to a depth of $15-20 \mathrm{~cm}$ to capture the majority of root material that interacted with surface deposition of metals. Soil collected with each excavation was placed into a high-density polyethylene tub, thoroughly mixed and quartered, and a
Table 1. List of sampling sites and locations and plant species sampled $(n=3)$ in each.

\begin{tabular}{|c|c|c|c|}
\hline Site & Location & Species & $\begin{array}{c}\text { Functional } \\
\text { group }\end{array}$ \\
\hline CO range & Berm & Elymus macrourus (Turcz.) Tzvelev & Grass \\
\hline CO range & Berm & Oxytropis campestris (L.) DC. & Forb \\
\hline CO range & Berm base & Achillea borealis Bong. & Forb \\
\hline CO range & Berm base & Elaeagnus commutata Bernh. ex Rydb. & Shrub \\
\hline OP7 & Burn pan & Elymus macrourus & Grass \\
\hline TX range & Berm1 & Achillea borealis & Forb \\
\hline TX range & Berm1 & Agrostis scabra Willd. & Grass \\
\hline TX range & Berm1 & Deschampsia cespitosa (L.) P. Beauv. & Grass \\
\hline TX range & Berm2 & Achillea borealis & Forb \\
\hline TX range & Berm2 & Agrostis scabra & Grass \\
\hline TX range & Berm2 & Deschampsia cespitosa & Grass \\
\hline WA flats & BIP1 & Potentilla multifida Soják & Forb \\
\hline WA flats & BIP1 & Taraxacum officinale F.H. Wigg & Forb \\
\hline WA flats & BIP2 & Hordeum jubatum L. & Grass \\
\hline WA flats & BIP2 & Salix setchelliana C.R. Ball & Shrub \\
\hline WA flats & Tank target & Solidago decumbens Greene & Forb \\
\hline WA flats & TOW crater & Elaeagnus commutata & Shrub \\
\hline WA flats & TOW target & Oxytropis campestris & Forb \\
\hline
\end{tabular}

composite soil sample collected for analysis. Soils were shaken from each root system, and plant roots and shoots were washed separately and thoroughly through vigorous shaking in three separate changes of 18 megaohm deionized water. Excess moisture was removed by placing plant samples in paper towels and gently patting them dry. Root and shoot samples were then placed in labeled paper bags for subsequent analyses.

\section{Sample analyses}

Composite soil samples were air dried for $72 \mathrm{~h}$, sieved to $2 \mathrm{~mm}$, and bagged for chemical and physical property analysis. Plant root and shoot samples were oven-dried at $40^{\circ} \mathrm{C}$ for $72 \mathrm{~h}$, ground and homogenized, and then stored in glass distillation vials for metal analysis. Soil and plant tissue samples were analyzed by the US Army Corps of Engineers Environmental Laboratory for metal concentrations following modifications of USEPA method 3050. Briefly, subsamples were acid digested using nitric acid with a concentration of $5 \%(\mathrm{v}: \mathrm{v})$ ( $\mathrm{Sb}$ had a prior digestion with $5 \mathrm{~mL}$ concentrated $\mathrm{HCl}$ ) prior to analysis by inductively coupled plasma mass spectrometry using a Perkin Elmer NexION 300D ICP-MS following modifications of USEPA method 6020. Rhodium and $\mathrm{Bi}$ were added online as internal standards to correct for instrument drift. The instrument was calibrated on NIST-traceable heavy metal standards at $0,1,10$, and $100 \mu \mathrm{g} \mathrm{L}^{-1}$. A second source calibration verification standard was analyzed immediately after instrument calibration to ensure the response function was accurate. A verification standard was run for every 10 unknown samples, and analyte recoveries were verified to within $10 \%$ of the expected concentration. Detection limits for all metals in soils were $<0.2 \mathrm{mg} \mathrm{kg}^{-1} ;<0.4 \mathrm{mg} \mathrm{kg}^{-1}$ for $\mathrm{Cr}, \mathrm{Cu}$, and $\mathrm{Pb}$ in root and shoot samples, $\mathrm{Ni}$ in root samples, and $\mathrm{Sb}$ in shoot samples; $<0.6 \mathrm{mg} \mathrm{kg} \mathrm{kg}^{-1}$ for $\mathrm{Ni}$ in shoots; $<0.8 \mathrm{mg} \mathrm{kg}^{-1}$ for $\mathrm{Sb}$ in roots; and $4 \mathrm{mg} \mathrm{kg}^{-1}$ for $\mathrm{Zn}$ in roots and shoots. Soil subsamples were then further analyzed for physical and plant nutritional properties by Midwest Laboratories (Omaha, NE). 
Table 2. Mean total metal concentrations in sampling site soils and associated contaminant limits (mg kg $\left.{ }^{-1}\right)$.

\begin{tabular}{|c|c|c|c|c|c|c|c|c|}
\hline Site & Site Type & Location & $\mathrm{Cr}$ & $\mathrm{Cu}$ & $\mathrm{Ni}$ & $\mathrm{Pb}$ & $\mathrm{Sb}$ & $\mathrm{Zn}$ \\
\hline CO range & Small arms range & 1 & 13.3 & 173 & 12.2 & 4650 & 42 & 74.2 \\
\hline CO range & Small arms range & 2 & 12.7 & 11.6 & 12 & 16.7 & 0.3 & 36.8 \\
\hline OP-7 & Explosive detonation site & 1 & 115.5 & 57.5 & 89.5 & 189.3 & 3 & 45.5 \\
\hline TX range & Small arms range & 1 & 14.9 & 36.3 & 12.3 & 1090 & 6 & 37.1 \\
\hline TX range & Small arms range & 2 & 13.1 & 10.6 & 11.1 & 61.1 & 0.7 & 30.9 \\
\hline WA flats & Munition target site & 1 & 11.6 & 25.4 & 11.1 & 11 & 0.1 & 57.5 \\
\hline WA flats & Munition target site & 2 & 10 & 13.1 & 9.6 & 7.3 & 0.2 & 43.1 \\
\hline WA flats & Munition target site & 3 & 15.1 & 38.8 & 12.1 & 18.8 & 0.4 & 41.2 \\
\hline WA flats & Munition target site & 4 & 12.1 & 29.8 & 13.7 & 11.1 & 0.1 & 38.8 \\
\hline WA flats & Munition target site & 5 & 9.3 & 8.6 & 8.4 & 5.6 & 0.1 & 25.7 \\
\hline \multicolumn{3}{|c|}{ Maximum Contaminant Level (MCL) for Drinking Water ${ }^{\mathrm{a}}\left(\mu \mathrm{g} \mathrm{L}^{-1}\right)$} & 100 & 1300 & & 15 & 6 & \\
\hline \multicolumn{3}{|c|}{ Regional Screening Level (RSL) for Industrial Soil ${ }^{\mathrm{b}}\left(\mathrm{mg} \mathrm{kg}^{-1}\right)$} & & 47,000 & & 800 & 470 & 35,0000 \\
\hline
\end{tabular}

aUS EPA National Primary Drinking Water Regulations. United States Code of Federal Regulations 40 CFR 141

${ }^{b}$ US EPA Regional Screening Levels Summary Table. www.epa.gov. Accessed 28 September 2018.

\section{Statistical analyses}

Means and standard errors were calculated for metal concentrations, BCF, and TF for all sampled plant species and functional groups across all the sites. Analysis of variance was conducted on the data using SAS (SAS Version 9.4, SAS Institute, Cary, NC). Metal concentration effects in both roots and shoots were analyzed between species in each functional group and across functional groups. Non-normal data were log-transformed to achieve normality. Mean separation for BCF and TF values between plant functional groups for each metal was conducted using Tukey's leastsignificant difference test in SAS.

\section{Results}

A total of 54 plant samples were collected from 10 different locations on 4 different training sites in interior Alaska (Table 1). Of these, 9 were from 2 shrub species, 24 were from 5 forb species, and 21 were from 4 grass species.

\section{Metal concentrations in composite soils}

Concentrations of total $\mathrm{Cr}, \mathrm{Cu}, \mathrm{Ni}, \mathrm{Pb}, \mathrm{Sb}$, and $\mathrm{Zn}$ were detected in each of the composite site soils. The composite soil samples recovered from the small arms ranges contained the greatest concentrations of $\mathrm{Pb}$ and $\mathrm{Sb}$, of which both were elevated in small arms range soils (Table 2). Composite soil samples recovered from the explosive detonation sites contained the greatest concentrations of $\mathrm{Cr}, \mathrm{Cu}$, and $\mathrm{Ni}$ (Table 2). Munition target site composite soils, i.e., impact area soils, did not contain elevated concentrations of any sampled metal.

\section{Metal concentrations in roots}

Table 3 provides mean plant root heavy metal concentrations for the individual plant species assayed, as well as for the specific plant functional group. Grasses, as a mean functional group $(n=21)$, accumulated the greatest root concentrations of each metal assayed. Of the metals, the greatest root concentrations were observed for $\mathrm{Pb}$, at a mean concentration of $482 \mathrm{mg} \mathrm{kg}^{-1}$ and a maximum of $1568 \mathrm{mg} \mathrm{kg}^{-1}$ in Elymus macrourus $(n=6)$. The lowest root metal concentrations were observed for $\mathrm{Sb}$, at a mean concentration of $8 \mathrm{mg} \mathrm{kg}^{-1}$ non-detected for Hordeum jubatum $(n=3)$. Mean root concentrations of $\mathrm{Cr}, \mathrm{Cu}, \mathrm{Ni}$, and $\mathrm{Zn}$ ranged from 8 to $68 \mathrm{mg} \mathrm{kg}^{-1}$ with the Elymus sp. accumulating over $100 \mathrm{mg} \mathrm{kg}^{-1}$ of $\mathrm{Cu}$.

Forb species accumulated comparable concentrations of $\mathrm{Cu}, \mathrm{Pb}$, and $\mathrm{Zn}$ into roots $\left(29,21\right.$, and $40 \mathrm{mg} \mathrm{kg}^{-1}$, respectively, $n=24)$. $\mathrm{Cr}$, Ni, and $\mathrm{Sb}$ were accumulated at an order of magnitude lower concentrations $\left(1-6 \mathrm{mg} \mathrm{kg}^{-1}\right)$. Oxytropis campestris $(n=6)$ accumulated the greatest root concentrations of $\mathrm{Pb}$ and $\mathrm{Sb}$ (43 and $2 \mathrm{mg} \mathrm{kg}^{-1}$, respectively), whereas Taraxacum officinale $(n=3)$ accumulated the lowest root concentrations for these two metals $\left(<2 \mathrm{mg} \mathrm{kg}^{-1}\right)$.

The two shrub species accumulated the lowest concentrations of $\mathrm{Pb}$ and $\mathrm{Sb}$ among the three functional groups assayed. Mean root concentrations $(n=9)$ of $\mathrm{Pb}$ and $\mathrm{Sb}$ were 6 and $0.6 \mathrm{mg} \mathrm{kg}^{-1}$, respectively. The shrubs accumulated mean root concentrations of $\mathrm{Cu}$ and $\mathrm{Zn}$ at 21 and $50 \mathrm{mg} \mathrm{kg}^{-1}$, respectively. Salix setchelliana accumulated greater root concentrations of all metals except $\mathrm{Zn}$.

\section{Metal concentrations in shoots}

Across the three functional groups, grasses contained the greatest mean concentrations of $\mathrm{Pb}$ and $\mathrm{Sb}, 29$ and $1 \mathrm{mg} \mathrm{kg}^{-1}$, respectively (Table 3 ). The greatest shoot concentrations of both $\mathrm{Pb}$ and $\mathrm{Sb}$ were observed in E. macrourus. The lowest shoot concentrations of $\mathrm{Pb}$ and $\mathrm{Sb}$ were observed in H. jubatum $\left(<7 \mathrm{mg} \mathrm{kg}^{-1}\right)$. Accumulation of $\mathrm{Cr}, \mathrm{Cu}, \mathrm{Ni}$, and $\mathrm{Zn}$ ranged from a mean of $3 \mathrm{mg} \mathrm{kg}^{-1}$ for $\mathrm{Ni}$ to a high of $28 \mathrm{mg} \mathrm{kg}^{-1}$ for $\mathrm{Zn}$.

\section{Bioconcentration and translocation}

The bioconcentration factor (BCF) is the ratio of plant concentration to soil concentration, whereas the translocation factor (TF) is the ratio of shoot concentration to root concentration. Forbs were the only functional group able to accumulate high concentrations of $\mathrm{Cu}$ in their roots compared with soils, having a mean root BCF greater than 1 (Figure 1, Table 4). Mean $\mathrm{Zn}$ concentrations in forb roots were similar to soils $(\mathrm{BCF}=1)$, but all other metals were not accumulated in forb roots in higher concentrations from the soils $(\mathrm{BCF}<1)$. Grasses accumulated 
Table 3. Mean metal concentrations in roots and shoots of all sampled plant species and plant functional groups across all sites.

\begin{tabular}{|c|c|c|c|c|c|c|}
\hline & \multicolumn{6}{|c|}{ Roots $\left(\mathrm{mg} \mathrm{kg}^{-1}\right)$} \\
\hline & $\mathrm{Cr}$ & $\mathrm{Cu}$ & $\mathrm{Ni}$ & $\mathrm{Pb}$ & $\mathrm{Sb}$ & $\mathrm{Zn}$ \\
\hline \multicolumn{7}{|l|}{ Forb species } \\
\hline Achillea borealis & $2.51(0.34)$ & $25.04(3.29)$ & $5.43(0.90)$ & $22.54(10.84)$ & $0.40(0.05)$ & $41.77(9.65)$ \\
\hline Oxytropis campestris & $3.71(2.18)$ & $24.53(1.75)$ & $8.20(1.28)$ & $43.24(20.81)$ & $2.15(0.40)$ & $21.05(2.43)$ \\
\hline Potentilla multifida & $1.60(0.28)$ & $31.43(6.26)$ & $5.38(0.67)$ & $6.13(1.63)$ & BDLa & $81.43(13.42)$ \\
\hline Solidago decumbens & $11.81(3.98)$ & $60.40(12.21)$ & $7.35(2.39)$ & $4.70(0.55)$ & $0.52(\mathrm{NA}) \mathrm{b}$ & $50.17(0.39)$ \\
\hline Taraxacum officinale & $1.03(0.07)$ & $17.37(2.58)$ & $1.63(0.19)$ & $1.48(0.30)$ & BDL & $18.93(1.36)$ \\
\hline Forb Mean & $3.67(0.94)$ & $29.17(3.21)$ & $5.88(0.66)$ & $20.80(7.00)$ & $1.07(0.36)$ & $39.74(5.54)$ \\
\hline \multicolumn{7}{|l|}{ Grass Species } \\
\hline Agrostis scabra & $6.97(2.69)$ & $15.12(0.31)$ & $11.85(0.68)$ & $10.01(1.97)$ & $0.50(0.03)$ & $17.87(1.41)$ \\
\hline Deschampsia cespitosa & $6.79(2.46)$ & $17.54(2.25)$ & $12.64(1.20)$ & $28.64(17.24)$ & $0.70(0.22)$ & $27.48(6.38)$ \\
\hline Elymus macrourus & $11.46(2.19)$ & $163.00(61.70)$ & $11.50(1.69)$ & $1568.70(306.40)$ & $23.62(11.11)$ & $82.47(10.64)$ \\
\hline Hordeum jubatum & $9.81(1.70)$ & $66.50(21.29)$ & $13.07(1.13)$ & $5.39(0.86)$ & $\mathrm{BDL}$ & $97.17(10.97)$ \\
\hline Grass Mean & $8.79(1.22)$ & $67.78(22.98)$ & $12.13(0.61)$ & $481.60(184.60)$ & $8.27(4.68)$ & $50.40(8.11)$ \\
\hline \multicolumn{7}{|l|}{ Shrub Species } \\
\hline Elaeagnus commutata & $5.96(1.76)$ & $22.78(7.65)$ & $5.93(0.78)$ & $7.29(3.86)$ & $0.60(0.22)$ & $23.97(4.22)$ \\
\hline Salix setchelliana & $1.15(0.13)$ & $18.33(5.00)$ & $2.93(0.74)$ & $2.76(0.83)$ & $\mathrm{BDL}$ & $101.30(0.33)$ \\
\hline Shrub Mean & $4.35(1.39)$ & $21.30(5.20)$ & $4.93(0.74)$ & $5.78(2.61)$ & $0.60(0.22)$ & $49.76(13.18)$ \\
\hline & & & Shoots $\left(\mathrm{mg} \mathrm{kg}^{-1}\right)$ & & & \\
\hline \multicolumn{7}{|l|}{ Forb Species } \\
\hline Achillea borealis & $9.49(3.73)$ & $13.02(1.21)$ & $5.19(1.44)$ & $12.39(4.65)$ & $0.26(0.04)$ & $25.99(2.44)$ \\
\hline Oxytropis campestris & $3.49(0.30)$ & $10.25(1.61)$ & $4.57(0.84)$ & $23.09(10.76)$ & $0.79(0.21)$ & $20.33(0.99)$ \\
\hline Potentilla multifida & $1.86(0.15)$ & $9.30(0.34)$ & $2.70(0.19)$ & $4.19(1.79)$ & $\mathrm{BDL}$ & $68.47(15.69)$ \\
\hline Solidago decumbens & $9.37(3.77)$ & $15.40(12.25)$ & $2.75(0.50)$ & $1.22(0.30)$ & $\mathrm{BDL}$ & $66.17(6.28)$ \\
\hline Taraxacum officinale & $1.14(0.07)$ & $23.63(2.68)$ & $2.12(0.05)$ & $\mathrm{BDL}$ & $\mathrm{BDL}$ & $109.80(26.17)$ \\
\hline Forb Mean & $5.93(1.58)$ & $13.51(1.15)$ & $3.96(0.60)$ & $11.13(3.54)$ & $0.49(0.14)$ & $45.39(7.22)$ \\
\hline \multicolumn{7}{|l|}{ Grass Species } \\
\hline Agrostis scabra & $5.46(3.41)$ & $5.43(0.51)$ & $3.98(0.40)$ & $4.87(1.33)$ & $0.19(0.04)$ & $16.67(1.77)$ \\
\hline Deschampsia cespitosa & $9.30(3.89)$ & $5.00(0.58)$ & $3.76(0.39)$ & $7.06(2.41)$ & $\mathrm{BDL}$ & $16.27(1.61)$ \\
\hline Elymus macrourus & $4.47(1.59)$ & $17.26(5.94)$ & $0.97(0.18)$ & $79.32(21.02)$ & $1.71(0.44)$ & $33.18(6.45)$ \\
\hline Hordeum jubatum & $5.16(2.02)$ & $16.97(1.39)$ & $2.71(0.45)$ & 6.85 (NA) & BDL & $61.20(2.97)$ \\
\hline Grass Mean & $6.23(1.53)$ & $10.33(2.08)$ & $2.97(0.33)$ & $29.17(10.19)$ & $0.95(0.39)$ & $27.63(3.95)$ \\
\hline \multicolumn{7}{|l|}{ Shrub Species } \\
\hline Elaeagnus commutata & $1.50(0.17)$ & $5.79(0.42)$ & $3.09(0.19)$ & $0.90(0.19)$ & $0.22(\mathrm{NA})$ & $18.08(2.46)$ \\
\hline Salix setchelliana & $1.31(0.10)$ & $10.51(1.78)$ & $2.45(0.08)$ & 0.43 (NA) & $\mathrm{BDL}$ & $132.13(16.79)$ \\
\hline Shrub Mean & $1.44(0.12)$ & $7.36(0.98)$ & $2.87(0.16)$ & $0.82(0.18)$ & 0.22 (NA) & $56.10(19.68)$ \\
\hline
\end{tabular}

Standard errors are in parentheses.

${ }^{\mathrm{a}} \mathrm{BDL}=$ metal concentration was below detection limit for all replicate samples.

${ }^{\mathrm{b}} \mathrm{NA}=$ metal concentration was below detection limit for all but one sample so standard error was incalculable.

Table 4. Mean root metal bioconcentration factors (BCF, ratio of root concentration to soil concentration) of all sampled plant species and plant functional groups across all sites.

\begin{tabular}{llcccrr}
\hline & $\mathrm{Cr}$ & $\mathrm{Cu}$ & $\mathrm{Ni}$ & $\mathrm{Pb}$ & $\mathrm{Sb}$ & $\mathrm{Zn}$ \\
\hline Forb Species & Root:Soil & & & & & \\
$\quad$ Achillea borealis & & & & & & \\
$\quad$ Oxytropis campestris & $0.19(0.02)$ & $1.91(0.40)$ & $0.47(0.08)$ & $0.16(0.06)$ & $0.58(0.20)$ & $1.20(0.27)$ \\
$\quad$ Potentilla multifida & $0.30(0.16)$ & $1.64(0.68)$ & $0.84(0.17)$ & $0.38(0.16)$ & $0.05(0.01)$ & $0.66(0.17)$ \\
$\quad$ Solidago decumbens & $0.14(0.02)$ & $1.24(0.25)$ & $0.49(0.06)$ & $0.56(0.15)$ & $\mathrm{BDL}$ & $1.42(0.23)$ \\
$\quad$ Taraxacum officinale & $0.78(0.26)$ & $1.56(0.32)$ & $0.61(0.20)$ & $0.25(0.03)$ & $1.43(\mathrm{NA}) \mathrm{b}$ & $1.22(0.01)$ \\
$\quad$ Forb Mean & $0.09(0.01)$ & $0.68(0.10)$ & $0.15(0.02)$ & $0.13(0.03)$ & $\mathrm{BDL}$ & $0.33(0.02)$ \\
Grass Species & $0.27(0.06)$ & $1.56(0.23)$ & $0.54(0.07)$ & $0.27(0.06)$ & $0.49(0.19)$ & $0.98(0.13)$ \\
$\quad$ Agrostis scabra & & & & & \\
$\quad$ Deschampsia cespitosa & $0.49(0.18)$ & $0.92(0.23)$ & $1.02(0.07)$ & $0.10(0.05)$ & $0.45(0.22)$ & $0.54(0.06)$ \\
$\quad$ Elymus macrourus & $0.49(0.19)$ & $0.91(0.26)$ & $1.07(0.11)$ & $0.07(0.03)$ & $0.40(0.14)$ & $0.79(0.16)$ \\
$\quad$ Hordeum jubatum & $0.35(0.11)$ & $1.10(0.29)$ & $0.52(0.20)$ & $3.42(1.62)$ & $0.60(0.24)$ & $1.13(0.21)$ \\
$\quad$ Grass Mean & $0.98(0.17)$ & $5.08(1.63)$ & $1.36(0.12)$ & $0.74(0.12)$ & $\mathrm{BDL}$ & $2.25(0.26)$ \\
Shrub Species & $0.52(0.09)$ & $1.60(0.41)$ & $0.93(0.09)$ & $1.19(0.57)$ & $0.48(0.11)$ & $1.01(0.16)$ \\
$\quad$ Elaeagnus commutata & & & & & \\
$\quad$ Salix setchelliana & $0.48(0.14)$ & $1.15(0.25)$ & $0.46(0.06)$ & $0.49(0.22)$ & $1.95(1.10)$ & $0.63(0.11)$ \\
$\quad$ Shrub Mean & $0.12(0.01)$ & $1.40(0.38)$ & $0.31(0.08)$ & $0.38(0.12)$ & $\mathrm{BDL}$ & $0.63(0.11)$ \\
\hline
\end{tabular}

Standard errors are in parentheses.

${ }^{\mathrm{a}} \mathrm{BDL}=$ metal concentration was below detection limit for all replicate samples.

${ }^{\mathrm{b}} \mathrm{NA}=$ metal concentration was below detection limit for all but one sample so standard error was incalculable.

higher mean concentrations of $\mathrm{Cu}$ and $\mathrm{Pb}$ compared to soils, similar concentrations of $\mathrm{Ni}$ and $\mathrm{Zn}$, and low concentrations of $\mathrm{Cr}$ and $\mathrm{Sb}, \mathrm{a} \mathrm{BCF} \leq 0.5$ (Figure 1, Table 4). Shrubs accumulated higher mean concentrations of $\mathrm{Cu}$ and $\mathrm{Sb}$ compared to soils, similar concentrations of $\mathrm{Zn}$, and low concentrations of $\mathrm{Cr}, \mathrm{Ni}$, and $\mathrm{Pb}$ (Table 4). Between functional groups, grasses had a higher mean root $\mathrm{Cr}$ BCF value than forbs and a higher mean root $\mathrm{Ni} \mathrm{BCF}$ value than both forbs and shrubs (Figure 1). Shrubs had a higher mean root $\mathrm{Sb}$ BCF value than both forbs and grasses. No 
Table 5. Mean metal translocation factors (TF, ratio of shoot concentration to root concentration) of all sampled plant species and plant functional groups across all sites.

\begin{tabular}{lccccrr}
\hline & \multicolumn{7}{c}{ Shoot:Root } \\
\cline { 2 - 7 } & $\mathrm{Cr}$ & $\mathrm{Cu}$ & $\mathrm{Ni}$ & $\mathrm{Pb}$ & $\mathrm{Sb}$ & $\mathrm{Zn}$ \\
\hline Forb Species & & & & & & \\
$\quad$ Achillea borealis & $5.73(2.54)$ & $0.67(0.17)$ & $1.03(0.16)$ & $0.76(0.15)$ & $0.58(0.02)$ & $0.89(0.20)$ \\
$\quad$ Oxytropis campestris & $1.88(0.42)$ & $0.41(0.04)$ & $0.66(0.13)$ & $0.53(0.07)$ & $0.37(0.04)$ & $1.03(0.12)$ \\
$\quad$ Potentilla multifida & $1.22(0.16)$ & $0.32(0.07)$ & $0.53(0.11)$ & $0.86(0.38)$ & $\mathrm{BDL}^{\mathrm{a}}$ & $0.84(0.10)$ \\
$\quad$ Solidago decumbens & $0.75(0.18)$ & $0.29(0.09)$ & $0.42(0.07)$ & $0.28(0.11)$ & $\mathrm{BDL}$ & $1.32(0.12)$ \\
$\quad$ Taraxacum officinale & $1.11(0.03)$ & $1.40(0.19)$ & $1.33(0.14)$ & $0.58(0.21)$ & $\mathrm{BDL}$ & $5.67(1.11)$ \\
$\quad$ Forb Mean & $2.93(1.00)$ & $0.60(0.10)$ & $1.29(0.46)$ & $0.63(0.08)$ & $0.45(0.06)$ & $1.57(0.35)$ \\
Grass Species & & & & & $0.35)$ \\
$\quad$ Agrostis scabra & $0.54(0.17)$ & $0.54(0.17)$ & $0.34(0.03)$ & $0.48(0.06)$ & $0.31(0.05)$ & $0.97(0.14)$ \\
$\quad$ Deschampsia cespitosa & $2.48(1.26)$ & $0.27(0.04)$ & $0.30(0.05)$ & $0.38(0.09)$ & $\mathrm{BDL}$ & $0.75(0.15)$ \\
$\quad$ Elymus macrourus & $0.38(0.11)$ & $0.28(0.14)$ & $0.09(0.02)$ & $0.06(0.02)$ & $0.07(0.02)$ & $0.40(0.04)$ \\
$\quad$ Hordeum jubatum & $0.48(0.14)$ & $0.31(0.09)$ & $0.22(0.05)$ & $1.40(\mathrm{NA}) \mathrm{b}$ & $\mathrm{BDL}$ & $0.64(0.06)$ \\
$\quad$ Grass Mean & $0.97(0.36)$ & $0.31(0.05)$ & $0.24(0.03)$ & $0.36(0.08)$ & $0.16(0.06)$ & $0.70(0.08)$ \\
Shrub Species & & & & & \\
$\quad$ Elaeagnus commutata & $0.33(0.06)$ & $0.34(0.07)$ & $0.56(0.07)$ & $0.28(0.16)$ & $\mathrm{BDL}$ & $0.81(0.10)$ \\
$\quad$ Salix setchelliana & $1.17(0.16)$ & $0.74(0.35)$ & $0.98(0.30)$ & $0.36(\mathrm{NA})$ & $\mathrm{BDL}$ & $1.31(0.17)$ \\
$\quad$ Shrub Mean & $0.61(0.15)$ & $0.48(0.13)$ & $0.70(0.12)$ & $0.29(0.13)$ & $\mathrm{BDL}$ & $0.97(0.12)$ \\
\hline
\end{tabular}

Standard errors are in parentheses.

${ }^{\mathrm{a}} \mathrm{BDL}=$ metal concentration was below detection limit for all replicate samples.

${ }^{\mathrm{b}} \mathrm{NA}=$ metal concentration was below detection limit for all but one sample so standard error was incalculable.

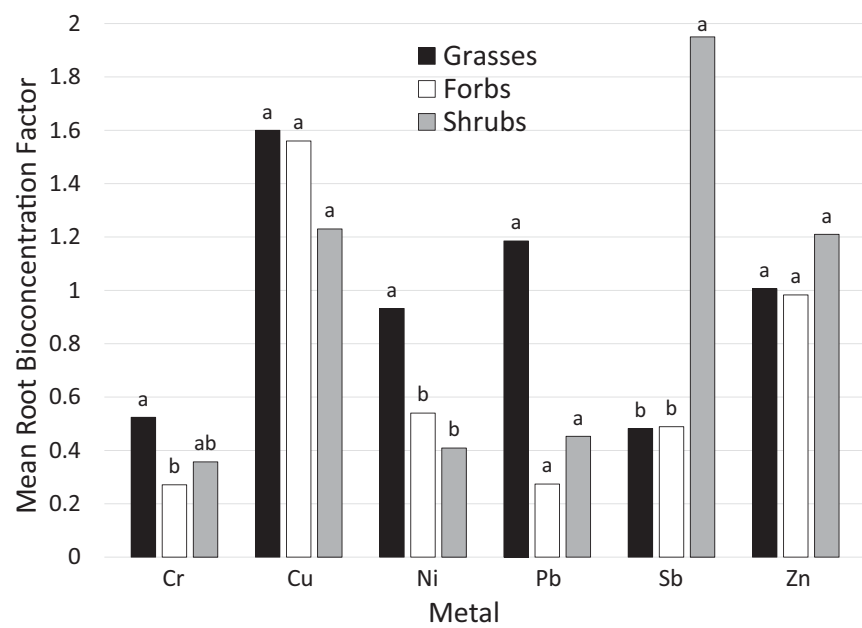

Figure 1. Mean root metal bioconcentration factors (BCF, the ratio of root concentration to soil concentration) for grasses, forbs, and shrubs sampled from Alaskan military lands. A high BCF $(>1)$ indicates higher root concentration compared to the soil. Mean BCF values for each metal with the same letter are not significantly different at an $\alpha=0.05$.

differences were observed in mean BCF values between grasses, forbs, and shrubs for $\mathrm{Cu}, \mathrm{Pb}$, and $\mathrm{Zn}$.

Forbs allowed translocation of high concentrations of $\mathrm{Cr}$, $\mathrm{Ni}$, and $\mathrm{Zn}$ to shoots ( $\mathrm{TF}>1$ ), while accumulated $\mathrm{Cu}, \mathrm{Sb}$, and $\mathrm{Pb}$ were retained in roots (Figure 2, Table 5). Grasses allowed a similar concentration of $\mathrm{Cr}$ to be translocated to shoots from roots, while all other metals were retained in roots (Figure 2, Table 5). Shrubs did not allow high concentrations of any metal to be translocated to shoots, while mean $\mathrm{Zn}$ concentration was similar between shrub roots and shoots (Figure 2, Table 5). Between functional groups, forbs had a higher mean TF value for $\mathrm{Cu}, \mathrm{Pb}, \mathrm{Sb}$, and $\mathrm{Zn}$ compared to grasses (Figure 2). Both forbs and shrubs had higher mean TF values for Ni compared to grasses. No differences existed between grasses, forbs, and shrubs for mean Cr TF (Figure 2).

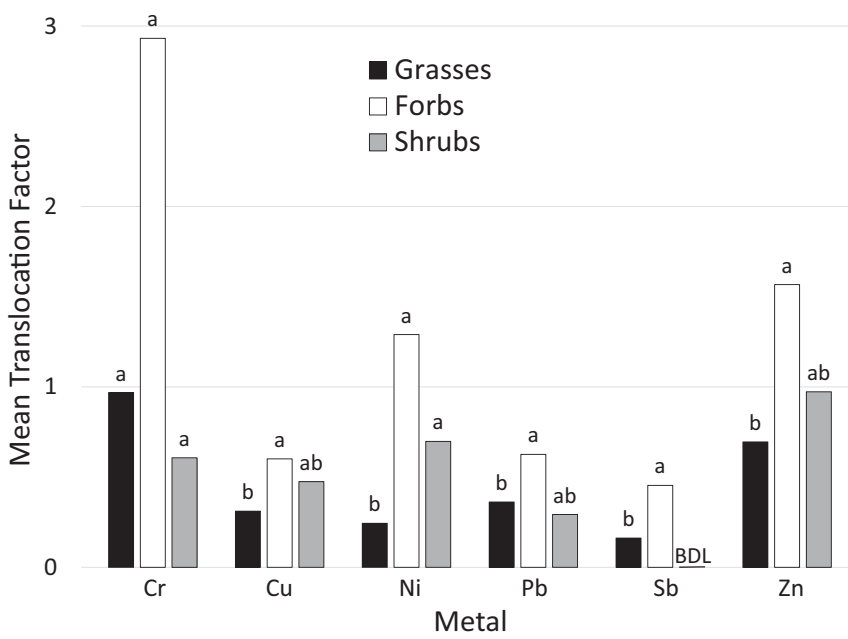

Figure 2. Mean metal translocation factors (TF, the ratio of shoot concentration to root concentration) for grasses, forbs, and shrubs sampled from Alaskan military lands. A high TF $(>1)$ indicates higher translocation to shoots compared to roots. Mean TF values for each metal with the same letter are not significantly different at an $\alpha=0.05$.

\section{Discussion}

Vegetation adapted to Arctic and subarctic environments are not adequately characterized with respect to interactions with metal deposition in soils. As permafrost thaw continues, coupled with increasing human activity in this locale, greater understanding of these interactions is necessary to maintain environmental quality. Our results indicate that vegetation indigenous to this environment possesses the potential for use in phytoremediation applications, but greater knowledge of species' differences and effects of environmental variation on performance is needed to effectively utilize phytoremediation technology for metal stabilization in high latitude environments.

In this study, the indigenous Alaska training range plants were highly variable in their accumulation of soil metals, 
concurrent with similar depositional trends worldwide. Forbs generally did not accumulate high concentrations of metals, in either roots or shoots. Any metal that was accumulated into the roots was also translocated to shoots, resulting in an even metal distribution across the plant. Of the forbs, only Solidago decumbens exhibited potential as a phytostabilizer, particularly for Sb. This plant species exhibited a BCF $>1$ and a TF of $<0.5$. Solidago canadensis, a congener to $S$. decumbens, has been previously shown to be an accumulator of $\mathrm{Cd}$ (Fu et al. 2017).

Shrubs generally did not accumulate high concentrations of metals in this study, but also did not translocate metal concentrations to shoots. Our shrub results further support the growing evidence that woody vegetation has high potential to concentrate $\mathrm{Sb}$ in roots and prevent translocation to shoots, which is important for stabilizing shooting range soils (Busby et al. 2018). Salix (willow) species are well known for their metal phytoextraction abilities (Gasronski et al. 2011). However, S. setchelliana was more effective at phytostablization than phytoextraction, as indicated by the accumulation of metals in roots and lower shoot metal concentrations, i.e., low translocation. However, the S. setchelliana samples collected in this study were growing in soil with low metal concentrations and previous research has indicated that metal accumulation in Salix tissues is highly dependent on soil metal concentrations (Tözsér et al. 2017).

Grasses, overall, accumulated the greatest root concentrations of metals and little evidence of translocation to shoots was observed. Of the grasses, E. macrourus and H. jubatum accumulated the highest concentrations of metals. Grasses are well documented for their ability to grow in soils high in metals and are one of the most important plant families for metal phytoremediation (Gasronski et al. 2011). Related species that have been previously investigated include Agrostis capillaris, which exhibited significant phytostabilization potential from a shooting range soil in Spain (Rodríguez-Seijo et al. 2016b), and Hordeum vulgare, which exhibited high root bioconcentration of metals and low translocation to shoots (Soriano-Disla et al. 2014).

Elymus macrourus has good potential as a metal phytostabilizer, accumulating the greatest root concentrations of $\mathrm{Cu}, \mathrm{Pb}$, and $\mathrm{Sb}$ and substantial amounts of $\mathrm{Cr}, \mathrm{Ni}$, and $\mathrm{Zn}$. It also possessed, by far, the highest root $\mathrm{Pb} \mathrm{BCF}$ of all sampled plant species. Low TF values for all analyzed metals were measured for E. macrourus. Unfortunately, because sampled plants were from a variety of soils with variable chemical and physical properties and levels of metal concentrations, a definitive conclusion that E. macrourus outperforms all other studied plant species for all analyzed metals cannot be made. However, samples of E. macrourus included samples from the soil with the highest $\mathrm{Pb}$ and $\mathrm{Sb}$ concentrations. In this soil, it accumulated greater root $\mathrm{Pb}$ and $\mathrm{Sb}$ concentrations compared to the other plant species, and with little apparent translocation of the metals to shoots. A controlled comparison between multiple plant species with E. macrourus in identical soils and varying levels of metal deposition would be needed to fully determine its potential as a phytostabilizer.
The soils sampled in this study varied considerably in metal concentrations. The impact area soils contained low concentrations of sampled metals, indicating that the management of metals at these sites is likely not necessary. However, the explosive detonation site soil and small arms range soils contained elevated levels of metals $(\mathrm{Cr}, \mathrm{Cu}, \mathrm{Ni}$, and $\mathrm{Pb}$ in the detonation site soil and $\mathrm{Cu}, \mathrm{Pb}, \mathrm{Sb}$, and $\mathrm{Zn}$ in the range soils). Of the sampled plant species exhibiting the greatest phytostabilization potential, only E. macrourus occurred in the soils with elevated metals; all others were only identified and sampled in the impact area soils. Overall, E. macrourus accumulated the highest concentrations of metals in its roots. Other species accumulating high root concentrations of at least one metal were $S$. decumbens, H. jubatum, and Salix setchelliana. These species also had root $\mathrm{BCF}$ values greater than 1 for at least one metal, while Elaeagnus commutata had the highest root BCF value for Sb. These species also possessed low metal TF values.

The plants analyzed in this study, on average, contained lower concentrations of $\mathrm{Cr}, \mathrm{Ni}$, and $\mathrm{Zn}$ but higher concentrations of $\mathrm{Cu}, \mathrm{Pb}$, and $\mathrm{Sb}$ compared to a meta-analysis of global mean metal concentrations in plants (Kumar et al. 2017). Of the metals assayed, $\mathrm{Cu}, \mathrm{Ni}$, and $\mathrm{Zn}$ are plant micronutrients and are present in low concentrations in healthy plants. The normal range of concentrations for shoot $\mathrm{Cu}$ is $5-20 \mathrm{mg} \mathrm{kg}^{-1}$, although many exceptions exist (Kabata-Pendias and Pendias 2001). The normal Ni content of most plant species is less than $5 \mathrm{mg} \mathrm{kg}^{-1}$ (Kabata-Pendias and Pendias 2001). Concentrations of $10-100 \mathrm{mg} \mathrm{kg}^{-1} \mathrm{Ni}$ are considered toxic for most plant species. Normal $\mathrm{Zn}$ concentrations in grasses range from 12 to $47 \mathrm{mg} \mathrm{kg}^{-1}$ worldwide, with clovers ranging from 24 to $45 \mathrm{mg} \mathrm{kg}^{-1}$ (KabataPendias and Pendias 2001). Most of the sampled plant species in this study did not exceed the normal concentration for these micronutrients, when examining shoot concentrations. However, root concentrations were often higher than the published normal ranges (Kabata-Pendias and Pendias 2001), which does coincide with the elevated metal concentrations observed in these training range soils.

Globally, few plant species have been investigated for their potential use to mitigate metal deposition in shooting range soils (Bandara and Vithanage 2016). Of those that have been studied, most are for phytoextraction, rather than phytostabilization, and most are not adapted to grow under conditions found in interior Alaska. Of a number of plants growing in soil containing elevated concentrations of $\mathrm{Sb}$ and $\mathrm{Pb}$ in Spain, a single grass species was identified as exhibiting phytostabilization capacity for $\mathrm{Pb}$ (Álvarez-Ayuso et al. 2012). On shooting range soils in Switzerland, a number of grass and forb shoots were analyzed for heavy metals, with only one forb species containing a high concentration of shoot $\mathrm{Pb}$ (Evangelou et al. 2012). In another Swiss shooting range soil with much higher concentrations of heavy metals, some of the same plant species analyzed by Evangelou et al. (2012) accumulated high shoot concentrations that would be considered toxic to livestock (Robinson et al. 2008). However, roots were not analyzed in these studies so the 
phytostabilization potentials of these plants cannot be discussed.

In a boreal forest environment in Finland, $\mathrm{Pb}$ from shooting range soils resulted in increased $\mathrm{Pb}$ concentrations in multiple organisms, $\mathrm{Pb}$ leaching from organic soil layers, and reduced abundances of numerous soil dwelling organisms (Selonen et al. 2012, 2014; Selonen and Setälä 2017). Grass litter with higher $\mathrm{Pb}$ concentrations decomposed more slowly in this environment (Selonen and Setälä 2015). This indicates phytostabilization of such soils would reduce the potential for $\mathrm{Pb}$ migration, as the $\mathrm{Pb}$ that accumulates in the stabilizers would decompose slowly and be held in the organic matter where it was taken up.

A combination of grasses, forbs, and shrubs that are most capable of metal phytostabilization would be most beneficial to the ecosystem as a whole, as plant functional diversity improves ecosystem functioning and resilience (Hooper and Vitousek 1997; Walker et al. 1999). The best performing grass, forb, and shrub could be utilized together across their adapted range to better ensure metal stabilization across a range of environmental conditions. Unfortunately, none of the most capable studied species possesses a circumpolar distribution (Hultén 1968; Welsh 1974). The native range of E. macrourus does stretch into Siberia, but its North American range is confined to Alaska and northwest Canada, where it occurs in tundra, woodlands, and riverbanks on sandy and gravelly soils. S. decumbens occurs in meadows and open woods across the United States and Canada, while E. commutata occurs on dry slopes, gravel bars, and open woods across the United States and Canada. $H$. jubatum is considered a weed in many locations and has been introduced outside its native range of northern North America and Siberia to most continents, and its metal phytostabilization capacity was lesser than E. macrourus.

In conclusion, grasses indigenous to interior Alaska were most effective at metal accumulation in roots, in particular Elymus macrourus. Forbs were not effective at metal accumulation and did not restrict translocation to shoots. Shrubs did not accumulate high metal concentrations, but what was accumulated remained in roots, in particular Sb. It is recommended that a combination of the best performing grass, forb, and shrub species be used in combination for metal stabilization in interior Alaska to enhance functional diversity while maximizing metal stabilization.

\section{Funding}

This research was funded by the United States Army Environmental Quality 6.2 Applied Research Program.

\section{References}

Ahmad M, Loo SS, Moon DH, Yang JE, Ok YS. 2012. A review of environmental contamination and remediation strategies for heavy metals at shooting range soils. In: Malik A, Grohmann E, editors. Environmental protection strategies for sustainable development: strategies for sustainability. Dordrecht (DE): Springer. p. 437-451.

Ali H, Khan E, Sajad MA. 2013. Phytoremediation of heavy metalsconcepts and applications. Chemosphere. 91(7):869-881. doi:10. 1016/j.chemosphere.2013.01.075.

Álvarez-Ayuso E, Otones V, Murciego A, García-Sánchez A, Santa Regina I. 2012. Antimony, arsenic and lead distribution in soils and plants of an agricultural area impacted by former mining activities. Sci Total Environ. 439:35-43. doi:10.1016/j.scitotenv.2012.09.023.

Bandara T, Vithanage M. 2016. Phytoremediation of shooting range soils. In: Ansari AA, Gill SS, Gill R, Lanza GR, Newman L. editors. Phytoremediation: management of environmental contaminants. Vol. 3. Cham (CH): Springer. p. 469-488.

Brown D, Jorgenson MT, Douglas TA, Romanovsky VE, Kielland K, Hiemstra C, Euskirchen ES, Ruess RW. 2015. Interactive effects of wildfire and climate on permafrost degradation in Alaskan lowland forests. J Geophys Res Biogeosci. 120(8):1619-1637. doi:10.1002/ 2015JG003033.

Busby RR, Barbato RA, Jung CA, Morozova KA, Bednar AJ, Bray AL, Milam JM, Smith JC, Indest KJ. 2018. Photoperiod and soil munition constituent effects on phytoaccumulation and rhizosphere interactions in boreal vegetation. Water Air Soil Pollut. 229(12):380. doi: 10.1007/s11270-018-4027-3.

Conesa HM, Evangelou MWH, Robinson BH, Schulin R. 2012. A critical review of current state of phytotechnologies to remediate soils: still a promising tool?. Sci World J. 2012:1. doi:10.1100/2012/173829.

Douglas T, Jones MC, Hiemstra CA, Arnold JR. 2014. Sources and sinks of carbon in boreal ecosystems of interior Alaska: a review. Elementa-Sci Anthrop. 12:2. doi:10.12952/journal.elementa.000032.

Evangelou MWH, Hockmann K, Pokharel R, Jakob A, Schulin R. 2012. Accumulation of $\mathrm{Sb}, \mathrm{Pb}, \mathrm{Cu}, \mathrm{Zn}$, and $\mathrm{Cd}$ by various plants species on two different relocated military shooting range soils. J Environ Manage. 108:102-107. doi:10.1016/j.jenvman.2012.04.044.

Frey KE, McClelland JW. 2009. Impacts of permafrost degradation on arctic river biogeochemistry. Hydrol Process. 23(1):169-182. doi:10. 1002/hyp.7196.

Fu W, Huang K, Cai HH, Li J, Zhai DL, Dai ZC, Du DL. 2017. Exploring the potential of naturalized plants for phytoremediation of heavy metal contamination. Int J Environ Res. 11(4):515-521. doi:10.1007/s41742-017-0045-z.

Gasronski SW, Greger M, Gawronska H. 2011. Plant taxonomy and metal phytoremediation. In: Sherameti I, Varma A, editors. Detoxification of heavy metals. Berlin (DE): Springer-Verlag. p. 91-109.

Hooper DU, Vitousek PM. 1997. The effects of plant composition and diversity on ecosystem processes. Science. 277(5330):1302-1305. doi: 10.1126/science.277.5330.1302.

Hultén E. 1968. Flora of Alaska and neighboring territories. Stanford (CA): Stanford University Press.

Kabata-Pendias A, Pendias H. 2001. Trace elements in soils and plants. Boca Raton (FL): CRC Press.

Kumar V, Sharma A, Dhunna G, Chawla A, Bhardwaj R, Thukral AK. 2017. A tabulated review on distribution of heavy metals in various plants. Environ Sci Pollut Res Int. 24(3):2210-2260. doi:10.1007/ s11356-016-7747-1.

Martin WA, Felt DR, Larson SL, Fabian GL, Nestler CC. 2012. Open burn/open detonation (OBOD) area management using lime for explosives transformation and metals immobilization. Vicksburg (MS): United States Army Corps of Engineers Environmental Laboratory Technical Report TR-12-4.

O'Donnell JA, Jorgenson MT, Harden JW, McGuire AD, Kanevskiy MZ, Wickland KP. 2012. The effects of permafrost thaw on soil hydrologic, thermal, and carbon dynamics in Alaskan peatland. Ecosystems. 15(2):213-229. doi:10.1007/s10021-011-9504-0. 
Padmavathiamma PK, Li LY. 2007. Phytoremediation technology: hyper-accumulation metals in plants. Water Air Soil Pollut. 184(1-4):105-126. doi:10.1007/s11270-007-9401-5.

Pinto AP, de Varennes A, Fonseca R, Teixeria DM. 2015. Phytoremediation of soils contaminated with heavy metals: techniques and strategies. In: Ansari AA, Gill SS, Gill R, Lanza GR, Newman L, editors. Phytoremediation: management of environmental contaminants. Vol. 1. Cham (CH): Springer. p. 133-155.

Reeves RD, Baker AJM, Jaffré T, Erskine PD, Echevarria G, van der Ent A. 2018. A global database for plants that hyperaccumulate metal and metalloid trace elements. New Phytol. 218(2):407-411. doi:10.1111/nph.14907.

Robinson BH, Bischofberger S, Stoll A, Schroer D, Furrer G, Roulier S, Gruenwald A, Attinger W, Schulin R. 2008. Plant uptake of trace elements on a Swiss military shooting range: uptake pathways and land management implications. Environ Pollut. 153(3):668-676. doi: 10.1016/j.envpol.2007.08.034.

Rodríguez-Seijo A, Alfaya MC, Andrade ML, Vega FA. 2016a. Copper, chromium, nickel, lead, and zinc levels and pollution degree in firing range soils. Land Degrad Develop. 27(7):1721-1730. doi:10.1002/ ldr.2497.

Rodríguez-Seijo A, Lago-Vila M, Luisa Andrade M, Vega FA. 2016 b. $\mathrm{Pb}$ pollution in soils from a trap shooting range and the phytoremediation ability of Agrostis capillaris L. Environ Sci Pollut Res. 23(2): 1312-1323. doi:10.1007/s11356-015-5340-7.

Sanderson P, Naidu R, Bolan N, Bowman M, Mclure S. 2012. Effect of soil type on distribution and bioaccessibility of metal contaminants in shooting range soils. Sci Total Environ. 438:452-462. doi:10.1016/ j.scitotenv.2012.08.014.

Selonen S, Liiri M, Setälä H. 2014. Can the soil fauna of boreal forests recover from lead-derived stress in a shooting range area? Ecotoxicology. 23(3):437-448. doi:10.1007/s10646-014-1210-1.
Selonen S, Liiri M, Strömmer R, Setälä H. 2012. The fate of lead at abandoned and active shooting ranges in a boreal pine forest. Environ Toxicol Chem. 31(12):2771-2779. doi:10.1002/etc.1998.

Selonen S, Setälä H. 2015. Soil processes and tree growth at shooting ranges in a boreal forest reflect contamination history and leadinduced changes in soil food webs. Sci Total Environ. 518-519: 320-327. doi:10.1016/j.scitotenv.2015.03.018.

Selonen S, Setälä H. 2017. Nutrient leaching, soil $\mathrm{pH}$ and changes in microbial community increase with time in lead-contaminated boreal forest soil at a shooting range area. Environ Sci Pollut Res. 24(6):5415-5425. doi:10.1007/s11356-016-8278-5.

Soriano-Disla JM, Gómez I, Navarro-Pedreño J, Jordán M. 2014. The transfer of heavy metals to barley plants from soils amended with sewage sludge with different heavy metal burdens. J Soils Sediments. 14(4):687-696. doi:10.1007/s11368-013-0773-4.

Tőzsér D, Magura T, Simon E. 2017. Heavy metal uptake by plant parts of willow species: a meta-analysis. J Hazard Mater. 336: 101-109. doi:10.1016/j.jhazmat.2017.03.068.

Walker B, Kinzig A, Langridge J. 1999. Plant attribute diversity, resilience, and ecosystem function: the nature and significance of dominant and minor species. Ecosystems. 2(2):95-113. doi:10.1007/ s100219900062.

Walsh ME. 2004. Field-portable X-ray fluorescence (FP-XRF) determinations of metals in post-blast ordnance residues. Hanover (NH): United States Army Corps of Engineers Cold Regions Research and Engineering Laboratory Technical Report TR-04-5.

Welsh SL. 1974. Anderson's flora of Alaska and adjacent parts of Canada. Provo (UT): Brigham Young University Press.

Zhuang P, Yang Q, Wang H, Shu W. 2007. Phytoextraction of heavy metals by eight plant species in the field. Water Air Soil Pollut. 184(1-4):235-242. doi:10.1007/s11270-007-9412-2. 


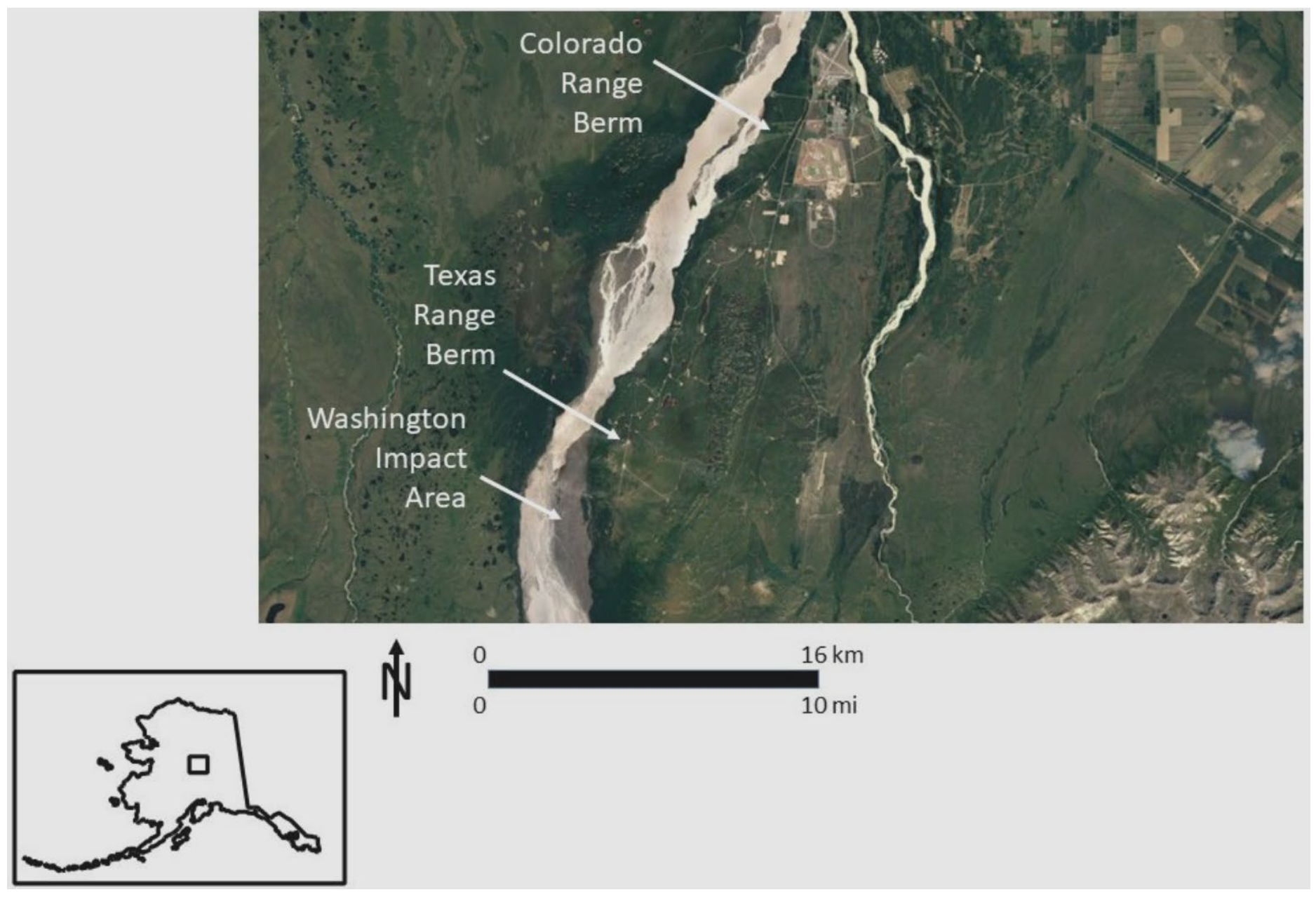




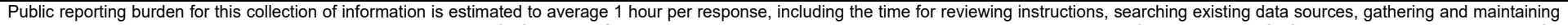

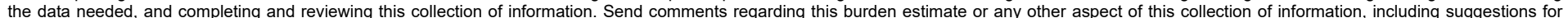

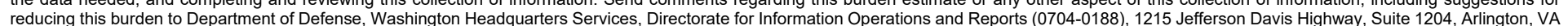

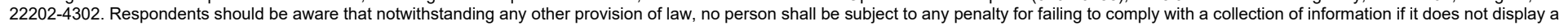
currently valid OMB control number. PLEASE DO NOT RETURN YOUR FORM TO THE ABOVE ADDRESS.

\begin{tabular}{|c|c|}
\hline $\begin{array}{c}\text { 1. REPORT DATE } \\
\text { August } 2021\end{array}$ & 2. REPORT TYPE \\
Final
\end{tabular}

\section{TITLE AND SUBTITLE}

Metal accumulation capacity in indigenous Alaska vegetation growing on military training lands

3. DATES COVERED (From - To)

5a. CONTRACT NUMBER

5b. GRANT NUMBER

5c. PROGRAM ELEMENT NUMBER

5d. PROJECT NUMBER

6. AUTHOR(S)

Ryan R. Busby, Thomas A. Douglas, Joshua J. LeMonte, David B. Ringelberg, and Karl J. Indest

\section{PERFORMING ORGANIZATION NAME(S) AND ADDRESS(ES)}

See next page.

9. SPONSORING / MONITORING AGENCY NAME(S) AND ADDRESS(ES)

U.S. Army Corps of Engineers

Washington, DC 20314

\section{5e. TASK NUMBER}

\section{5f. WORK UNIT NUMBER}

8. PERFORMING ORGANIZATION REPORT NUMBER

ERDC MP-21-10

10. SPONSOR/MONITOR'S ACRONYM(S)

11. SPONSOR/MONITOR'S REPORT NUMBER(S)

\section{DISTRIBUTION / AVAILABILITY STATEMENT}

Approved for public release; distribution is unlimited.

\section{SUPPLEMENTARY NOTES}

This article was originally published online in the International Journal of Phytoremediation on 23 February 2020.

This research was funded by the U.S. Army Environmental Quality 6.2 Applied Research Program.

\section{ABSTRACT}

Permafrost thawing could increase soil contaminant mobilization in the environment. Our objective was to quantify metal accumulation capacities for plant species and functional groups common to Alaskan military training ranges where elevated soil metal concentrations were likely to occur. Plant species across multiple military training range sites were collected. Metal content in shoots and roots was compared to soil metal concentrations to calculate bioconcentration and translocation factors. On average, grasses accumulated greater concentrations of $\mathrm{Cr}, \mathrm{Cu}, \mathrm{Ni}, \mathrm{Pb}, \mathrm{Sb}$, and $\mathrm{Zn}$ relative to forbs or shrubs, and bioconcentrated greater concentrations of $\mathrm{Ni}$ and $\mathrm{Pb}$. Shrubs bioconcentrated greater concentrations of Sb. Translocation to shoots was greatest among the forbs. Three native plants were identified as candidate species for use in metal phytostabilization applications. Elymus macrourus, a grass, bioconcentrated substantial concentrations of $\mathrm{Cu}, \mathrm{Pb}$, and $\mathrm{Zn}$ in roots with low translocation to shoots. Elaeagnus commutata, a shrub, bioconcentrated the greatest amounts of $\mathrm{Sb}, \mathrm{Ni}$, and $\mathrm{Cr}$, with a low translocation factor. Solidago decumbens bio-concentrated the greatest amount of $\mathrm{Sb}$ among the forbs and translocated the least amount of metals. A combination of forb, shrub, and grass will likely enhance phytostabilization of heavy metals in interior Alaska soils through increased functional group diversity.

\section{SUBJECT TERMS}

Boreal forest; Elymus macrourus; phytoremediation; phytostabilization

16. SECURITY CLASSIFICATION OF:
\begin{tabular}{|c|c|c|}
\hline a. REPORT & b. ABSTRACT & c. THIS PAGE \\
Unclassified & Unclassified & Unclassified \\
\hline
\end{tabular}

\begin{tabular}{c|c}
$\begin{array}{l}\text { 17. LIMITATION } \\
\text { OF ABSTRACT }\end{array}$ & $\begin{array}{c}\text { 18. NUMBER } \\
\text { OF PAGES }\end{array}$ \\
UU & 15 \\
\hline
\end{tabular}

\section{9a. NAME OF RESPONSIBLE PERSON}

19b. TELEPHONE NUMBER (include area code) 
Construction Engineering Research Laboratory U.S. Army Engineer Research and Development Center 2902 Newmark Drive

Champaign, IL 61822

Cold Regions Research and Engineering Laboratory U.S. Army Engineer Research and Development Center Fort Wainwright, AK

Cold Regions Research and Engineering Laboratory U.S. Army Engineer Research and Development Center 72 Lyme Road

Hanover, NH 03755

Environmental Laboratory

U.S. Army Engineer Research and Development Center 3909 Halls Ferry Road

Vicksburg, MS 39180 